\title{
Preliminary assessment of benthic community metabolism in a south-east Asian mangrove swamp
}

\author{
Erik Kristensen, Frede Ø. Andersen, Lars H. Kofoed \\ Institute of Biology, University of Odense, DK-5230 Odense M, Denmark
}

\begin{abstract}
Preliminary data are presented on benthic metabolism, i.e. carbon, oxygen and dissolved inorganic nitrogen (DIN) dynamics in a tropical, south-east Asian mangrove swamp. Primary production by benthic microalgae, measured as ${ }^{14} \mathrm{C}$ assimilation and $\mathrm{O}_{2}$ production, was low compared to other intertidal areas. Benthic production comprised 4 to $20 \%$ of production estimates obtained from the literature on the mangrove Rhizophora apiculata. Factors responsible for the relatively low benthic primary production appeared to be shading by $R$. apiculata and DIN availability. Oxygen penetration into water-covered sediment showed significant differences between light $(2.5 \mathrm{~mm})$ and darkness $(1.5 \mathrm{~mm})$. In air-exposed sediment, however, $\mathrm{O}_{2}$ penetration depth was similar in both light and darkness. Oxygen uptake by the sediment obtained from core incubations was 20 to $55 \%$ higher than the rate estimated from vertical $\mathrm{O}_{2}$ profiles. The estimated $\mathrm{O}_{2}$ demand needed to support the decay of produced algal cells was ca $73 \%$ of the measured total $\mathrm{O}_{2}$ uptake by the sediment. Water sampling in a tidal channel indicated that suspended particles transported by incoming tides were trapped in the mangrove system. This tidal import was evident as an upper sedimentary silt-zone (0 to $5 \mathrm{~cm}$ ) superposing a lower peat containing root-zone $(>5 \mathrm{~cm})$ in the sediment.
\end{abstract}

\section{INTRODUCTION}

Mangrove swamps are usually considered to be areas of high primary productivity which support highly developed detritus-based food webs (e.g. Odum \& Heald 1975, Dye \& Lasiak 1986, Robertson 1986). It has long been recognized that mangrove trees, e.g. Rhizophora spp. and Avicennia spp., are the most important primary producers (Christensen 1978, Bunt et al. 1979, Twilley et al. 1986b). During the last decade various studies have been reported on primary production and sessile macroalgae in mangrove swamps (Wium-Andersen 1979, Ricard 1984, Davey \& Woelkerling 1985), but the role of benthic microalgae has not yet been addressed. Benthic microalgae, known as important producers of organic matter in intertidal flats all over the world (e.g. Colijn \& Jonge 1984), may be of significance for nutrient and detritus dynamics in mangrove swamps.

The decay of organic matter in mangroves has usually been determined as the time dependent weight loss of litter (Boonruang 1978, Cundell et al. 1979, Rice \& Tenore 1981). This has provided valuable informations about leaching and microbial attack on intact leaves, but less about the overall microbial activity in mangrove sediments.

Oxygen exchange, generally accepted as a measure of autotrophic and heterotrophic (aerobic as well as anaerobic) activity in sediments (Jørgensen 1983, Andersen \& Hargrave 1984, Kristensen \& Blackburn 1987), may provide the basis for an estimate of primary production and decomposition by the benthic community. The results can without serious error be converted to carbon flux using a conversion factor of 1 (Andersen \& Kristensen 1988).

The present paper is a preliminary study on benthic metabolism, i.e. primary production, $\mathrm{O}_{2}$ uptake and inorganic nitrogen dynamics, within a south-east Asian mangrove swamp. Benthic metabolism was determined from in situ measurements of ${ }^{14} \mathrm{CO}_{2}, \mathrm{O}_{2}$ and inorganic nitrogen exchange across the sedimentwater interface. The influence of light intensity on benthic metabolism and oxygen penetration depth was determined on sediments either being shaded by Rhizophora apiculata or exposed to direct sunlight. The role of the benthic community for turnover of organic matter in the present mangrove system is evaluated. 


\section{MATERIALS AND METHODS}

Study site. The work was carried out during January 1987 in the Ao Nam Bor mangrove; a small mangrove swamp on the southeast coast of Phuket Island, Thailand (Frith et al. 1976, Christensen 1978). This swamp, which is only about $200 \mathrm{~m}$ wide from inland to seaward edge at the study site, is bordered by a ca $500 \mathrm{~m}$ wide vegetation free tidal flat. There is no freshwater outflow, other than drainage water from the adjacent mainland during heavy rains. The macrophyte flora is dominated by the mangrove Rhizophora apiculata (Bl.) and the benthic macrofauna mainly consist of crabs (Ocypodidae and Grapsidae), snails (Cerithiidae), mudskippers (Gobioidea) and sipunculid worms (Frith et al. 1976).

Tidal range in the area is ca $2 \mathrm{~m}(1.0$ to $2.5 \mathrm{~m})$. The study site, however, is usually not covered by more than $1 \mathrm{~m}$ during high tide. On average, the sediment surface is inundated for $4 \mathrm{~h}$ per day and exposed to air for $20 \mathrm{~h}$ (except for small permanent pools). During high tide, salinity and water temperature are $35 \%$ and $28^{\circ} \mathrm{C}$ respectively. However, at low tide during daytime the temperature of exposed sediment surfaces may rise to 35 to $38^{\circ} \mathrm{C}$.

Measurements were made at 2 stations ca $30 \mathrm{~m}$ from the seaward fringe of the mangrove forest and ca $15 \mathrm{~m}$ from a tidal creek (subzone $3 b$ in Frith et al. 1976). The 2 stations, named SUN and SDW, were ca $5 \mathrm{~m}$ apart. The SUN station was exposed to direct sunlight 6 to $8 \mathrm{~h}$ a day (at noon: $2700 \mu \mathrm{E} \mathrm{m}^{-2} \mathrm{~s}^{-1}$ ), whereas the SDW station was permanently shadowed by 'prop' roots and dense growth of Rhizophora apiculata (at noon: $288 \mu \mathrm{E}$ $\mathrm{m}^{-2} \mathrm{~s}^{-1}$ ).

Sediment handling. Cores for determination of sediment characteristics were sampled by hand with $5.6 \mathrm{~cm}$ i.d. plexiglass corers. Sediment cores were processed within $2 \mathrm{~h}$ after sampling. Those used for determination of density, porosity, organic content and dissolved inorganic nitrogen. (DIN) were cut into $0-1,1-2,2-3,3-4$, $4-6,6-8,8-10 \mathrm{~cm}$ sections.

Sediment density was determined from the weight and volume of wet sediment samples. Porosity was calculated from the water loss at $100^{\circ} \mathrm{C}$ for $12 \mathrm{~h}$. Sediment organic content was measured by weight as (1) loss-on-ignition (LOI) at $500^{\circ} \mathrm{C}$ for $12 \mathrm{~h}_{i}$ (2) particulate organic carbon ( $\mathrm{POC}$ ); (3) particulate organic nitrogen (PON) as described by Kristensen \& Andersen (1987). POC and PON were analysed by a Hewlett-Packard 185 B CHN-analyzer.

Pore water was obtained from sediment samples by centrifugation for $10 \mathrm{~min}$ at $580 \mathrm{~g}$ in double centrifuge tubes (Andersen \& Kristensen 1988). The supernatant was stored frozen until analysis in duplicates by the standard autoanalyzer methods of Solórzano (1969) for
$\mathrm{NH}_{4}{ }^{+}$and of Armstrong et al. (1967) for $\mathrm{NO}_{2}{ }^{-}$and $\mathrm{NO}_{3}$. Since the measured $\mathrm{NO}_{2}{ }^{-}$concentrations generally were less than $10 \%$ of the $\mathrm{NO}_{3}{ }^{-}$results, $\mathrm{NO}_{2}{ }^{-}$will be included with the presented $\mathrm{NO}_{3}{ }^{-}$data.

Chlorophyll a content of surface sediment was determined in 3 replicates from each station. Each replicate (ca $2 \mathrm{~g}$ wet wt) consisted of 6 pooled samples, taken to a depth of $3 \mathrm{~mm}$ by a $7 \mathrm{~mm}$ i.d. glass tube. After sampling, replicates were added 1 to 2 drops of saturated $\mathrm{MgCO}_{3}$ solution and extracted in $12 \mathrm{ml} 90 \%$ acetone. The mixture was vortexed for 1 min and kept in darkness at $5{ }^{\circ} \mathrm{C}$ overnight. The next day, after vortexing again, the supernatant was centrifuged for $5 \mathrm{~min}$ at $580 \mathrm{~g}$. Absorbance at 665 and $750 \mathrm{~nm}$ was measured before and after acidification by one drop of $2 \mathrm{~N} \mathrm{HCl}$. Subsequent extractions, which revealed no detectable pigment absorbance, indicated a $100 \%$ extraction efficiency. The chlorophyll a content was calculated according to the method of Parsons et al. (1984a).

Oxygen measurements by mini-electrodes. Depth of $\mathrm{O}_{2}$ penetration inhto the sediment was measured by a membrane-coated polarographic $760 \mathrm{O}_{2}$ needle electrode (Diamond Electro-Tech, Inc.) with a platinum tip diameter of 35 to $40 \mu \mathrm{m}$ (outer diameter $700 \mu \mathrm{m}$ ). Spatial resolution was less than $0.5 \mathrm{~mm}$ (Helder \& Bakker 1985). The electrode was mounted on a manually driven micromanipulator, connected to an ammeter (Keithly 480 digital picoammeter) and recorded on a Minigor RE 501 (Goerz Electro) recorder.

Light and dark $\mathrm{O}_{2}$ profiles from the 2 stations were obtained at in situ conditions. Profiles were measured in steps of $0.5 \mathrm{~mm}$ on cores both with and without a nonstirred water column $(10 \mathrm{~mm}$ water depth). Light intensity was SUN: 1154 to $1538 \mu \mathrm{E} \mathrm{m}^{-2} \mathrm{~s}^{-2}$ and SDW: 115 to $346 \mu \mathrm{E} \mathrm{m}^{-2} \mathrm{~s}^{-1}$.

The diffusive flux of $\mathrm{O}_{2}$ into the sediment was estimated from the steepest gradient below the sediment surface $(0.5$ to $1.0 \mathrm{~mm})$ by the one-dimensional version of Fick's first law of diffusion (Berner 1980):

$$
\mathrm{J}=-\phi \mathrm{D}_{\mathrm{s}} \Delta\left[\mathrm{O}_{2}\right] / \Delta \mathrm{z}
$$

Where $\mathrm{J}=$ flux of $\mathrm{O}_{2}$ into the sediment $\left(\mathrm{umol} \mathrm{m}^{-2} \mathrm{~h}^{-1}\right)$; $\mathrm{D}_{\mathrm{s}}=$ apparent diffusion coefficient of $\mathrm{O}_{2}$ in the sediment; $\phi=$ porosity; $\Delta\left[\mathrm{O}_{2}\right]=\mathrm{O}_{2}$ gradient in the $\Delta z=0.5$ to $1.0 \mathrm{~mm}$ layer of sediment. $\mathrm{D}_{\mathrm{s}}$ was calculated from the porosity $(\phi)$ data and the temperature corrected ( $\mathrm{Li} \&$ Gregory 1974) diffusion coefficient (D) of $\mathrm{O}_{2}$ in sea water $\left(\mathrm{D}=2.0 \times 10^{-5} \mathrm{~cm}^{2} \mathrm{~s}^{-1}\right.$ at $20^{\circ} \mathrm{C}$ and $35 \% \mathrm{~S}$; Broecker \& Peng 1974) by the method of Iversen \& Jørgensen (unpubl.)

${ }^{14} \mathrm{C}$ incubations. Carbon assimilation by benthic microalgae was determined in situ using a modified version of the ${ }^{14} \mathrm{C}-\mathrm{CO}_{2}$ technique described by Leach (1970). Surface sediment was sampled to a depth of ca $5 \mathrm{~mm}$ with a $7 \mathrm{~mm}$ i.d. piston equipped plastic tube. 
The samples were gently transferred to the bottom of $7 \mathrm{~mm}$ i.d. Durham glass tubes. Subsequently, the Durham tubes were placed in the sediment securing that the sediment surface inside the tubes were at the level of the outside sediment. At each station 4 tubes were handled. Fixation rates in light (not corrected for dark uptake of ${ }^{14} \mathrm{C}$ ) were assumed to reflect the net assimilation rates (Colijn \& Jonge 1984). To each tube was added $1 \mathrm{ml} \mathrm{GF} / \mathrm{C}$ filtered sea water containing $2 \mathrm{mM} \mathrm{TCO} 2$ and $0.1 \mu \mathrm{Ci}{ }^{14} \mathrm{C}-\mathrm{CO}_{2}\left(1.85 \mathrm{MBq} \mathrm{mmol}^{-1}\right)$. After $30 \mathrm{~min}$ the water phase was removed and the incubation was stopped by adding $4 \%$ formalin. The content of each Durham tube was transferred to $\mathrm{CO}_{2}$ permeable plastic scintillation vials. The samples were acidified with $2.5 \mathrm{ml} 0.5 \mathrm{~N} \mathrm{HCl}$, and added $7.5 \mathrm{ml}$ water and $10 \mathrm{ml}$ gelforming scintillation liquid (Hydrocount, J, T. Baker Chemicals). After vortexing the samples were counted for 40000 counts or $20 \mathrm{~min}$ in a Searle, Mark III, scintillation counter with a dpm correction option. The samples were counted twice over a period of 1 mo to assure that no labeled $\mathrm{TCO}_{2}$ remained.

Flux measurements. Exchanges of $\mathrm{O}_{2}$ and DIN at the 2 stations were determined from concentration changes during light and dark in situ incubations. At each station 4 transparent Plexiglass corers $(25 \mathrm{~cm}$ long and $5.6 \mathrm{~cm} \mathrm{i.d.)} \mathrm{were} \mathrm{pushed} 15$ to $20 \mathrm{~cm}$ into the sediment, leaving 5 to $10 \mathrm{~cm}$ of the corer above the sediment surface. The water phase of the inserted corers were gently replaced with $\mathrm{GF} / \mathrm{C}$ filtered sea water. The upper end of each corer was closed with a battery driven magnetic stirrer fitted to the opening, providing a water circulation well below the resuspension limit. During dark incubations the corers were wrapped in alu-foil. To prevent evolution of $\mathrm{O}_{2}$ bubbles during light incubations, and thus an underestimate of photosynthesis, the added water was vacuum-boiled to an $\mathrm{O}_{2}$ concentration of 28 to $59 \%$ of full air saturation. The water added initially during dark incubations was close to $\mathrm{O}_{2}$ saturation (73 to $93 \%$ ). Durations of light and dark incubations were 1.0 and $1.5 \mathrm{~h}$ respectively. Oxygen concentration in light never exceeded saturation, and in darkness never fell below $56 \%$ saturation. Oxygen was determined by the Winkler titration technique (Parsons et al. 1984a). DIN $\left(\mathrm{NH}_{4}{ }^{+}, \mathrm{NO}_{2}{ }^{-}, \mathrm{NO}_{3}{ }^{-}\right)$was analysed and presented as earlier described.

Import-export samplings. The concentration of particulate carbon (PC) and nitrogen (PN) and DIN in the water of a tidal channel adjacent to the study site was determined at daytime during one tidal cycle. A sampling site was chosen at the channel outlet near the seaward fringe of the mangrove forest. Representative water samples (sampling depth: 10 to $30 \mathrm{~cm}$ ) were taken at hourly intervals with a $60 \mathrm{ml}$ syringe. The water was immediately filtered through GF/C filters using a swinnex-25 filter holder (Millipore Corp.), and stored in vials at $-20^{\circ} \mathrm{C}$ until analysis for DIN $\left(\mathrm{NH}_{4}{ }^{+}\right.$, $\mathrm{NO}_{2}^{-}, \mathrm{NO}_{3}^{-}$). The filters were air dried and the content of PC and PN were determined on a CHN-analyzer

Statistical analysis. The Student-Newman-Keuls (SNK) multiple comparisons test of means was used to determine significant factors within the various vertical sediment profiles. Differences in pairs of means, e.g. between the 2 stations, were tested using a 1-way ANOVA (Model I) analysis of variance.

\section{RESULTS}

\section{Sediment characteristics}

Since no spatial difference was observed, sediment characteristics are presented as pooled data from the 2 stations.

Profiles of density, porosity, organic content and DIN in the Ao Nam Bor mangrove sediment showed 2 horizontal zones. The upper $4 \mathrm{~cm}$ was composed of fine grained silty sediment (density: 1.66 to $1.71 \mathrm{~g} \mathrm{~cm}^{-3}$; porosity: 0.63 to 0.70 ) (Table 1). Below this depth density and porosity decreased to 1.59 to $1.63 \mathrm{~g} \mathrm{~cm}^{-3}$ and 0.60 to 0.62 respectively, indicating a more densely packed lower strata composed of lighter peat material. Visual inspection confirmed the 2 layered structure; an upper ca $5 \mathrm{~cm}$ grey-brown zone of well sorted silty material (silt-zone) superposing a grey-black fibrous peat zone dominated by living and dead roots of Rhizophora apiculata (root-zone).

The organic content (measured as LOI, POC and PON) showed no significant changes with depth in the sediment (Table 1). However, a slight difference between the upper part of the silt-zone and the rootzone was evident for all 3 parameters. Thus, the $\mathrm{C}: \mathrm{N}$ molar ratio of the organic matter increased from 24 to 27 with depth in the silt-zone $(p<0.05)$, and remained constantly high (28 to 29 ) in the root-zone. The contribution of POC to the LOI values (24.3 to $25.6 \%$ ) appeared relatively low, but it was close to the range usually found for other sediments, i.e. 30 to $35 \%$ (Kristensen unpubl.). A fraction of the non-carbon LOI may, however, be clay or lattice bound water (Mook \& Hoskin 1982). Inorganic carbon (carbonates) generally accounted for ca $1 \%$ of the total carbon content at all depths.

Pore water $\mathrm{NH}_{4}{ }^{+}$and $\mathrm{NO}_{3}{ }^{-}$showed maximum concentrations ( 75 and $21 \mu M$, respectively) in the upper 2 to $3 \mathrm{~cm}$ (Fig. 1). For $\mathrm{NH}_{4}{ }^{+}$a slight, but not significant, decrease occurred below $3 \mathrm{~cm}$ depth. The profile of $\mathrm{NO}_{3}{ }^{-}$in Fig. 1 B, which unfortunately is based on only 1 sediment core (malfunction of the analytical equipment), showed a significantly higher concentration 
Table 1 Vertical profiles of wet density, porosity, loss-on-ignition (LOI), particulate organic carbon (POC), particulate organic nitrogen (PON) and $\mathrm{C}: \mathrm{N}$ molar ratio in sediments from the Ao Nam Bor mangrove. Mean values \pm SE of 4 measurements

\begin{tabular}{|lcccccc|}
\hline $\begin{array}{l}\text { Depth } \\
(\mathrm{cm})\end{array}$ & $\begin{array}{c}\text { Density } \\
\left(\mathrm{g} \mathrm{cm}^{-3}\right)\end{array}$ & $\begin{array}{c}\text { Porosity } \\
\left(\mathrm{cm}^{3} \mathrm{~cm}^{-3}\right)\end{array}$ & $\begin{array}{c}\text { LOI } \\
(\%)\end{array}$ & $\begin{array}{c}\text { POC } \\
(\%)\end{array}$ & $\begin{array}{c}\text { PON } \\
\left(10^{-2} \%\right)\end{array}$ \\
\hline $0-1$ & $1.66 \pm 0.02$ & $0.64 \pm 0.01$ & $7.36 \pm 0.43$ & $1.84 \pm 0.14$ & $9.2 \pm 0.5$ & $24.0 \pm 0.8$ \\
$1-2$ & $1.71 \pm 0.04$ & $0.70 \pm 0.03$ & $8.21 \pm 0.70$ & $2.07 \pm 0.21$ & $9.7 \pm 0.7$ & $24.8 \pm 1.0$ \\
$2-3$ & $1.68 \pm 0.05$ & $0.65 \pm 0.02$ & $8.22 \pm 0.61$ & $2.23 \pm 0.32$ & $9.9 \pm 0.5$ & $26.5 \pm 2.0$ \\
$3-4$ & $1.69 \pm 0.06$ & $0.63 \pm 0.03$ & $8.46 \pm 0.88$ & $2.30 \pm 0.59$ & $9.6 \pm 1.2$ & $26.7 \pm 3.3$ \\
$4-6$ & $1.59 \pm 0.05$ & $0.62 \pm 0.04$ & $9.24 \pm 0.93$ & $2.32 \pm 0.30$ & $9.7 \pm 1.1$ & $27.7 \pm 0.9$ \\
$6-8$ & $1.63 \pm 0.02$ & $0.60 \pm 0.03$ & $8.24 \pm 0.60$ & $2.15 \pm 0.18$ & $8.5 \pm 0.6$ & $29.4 \pm 0.5$ \\
$8-10$ & $1.64 \pm 0.02$ & $0.60 \pm 0.01$ & $8.40 \pm 0.39$ & $2.23 \pm 0.10$ & $9.0 \pm 0.6$ & $29.0 \pm 1.3$ \\
\hline
\end{tabular}

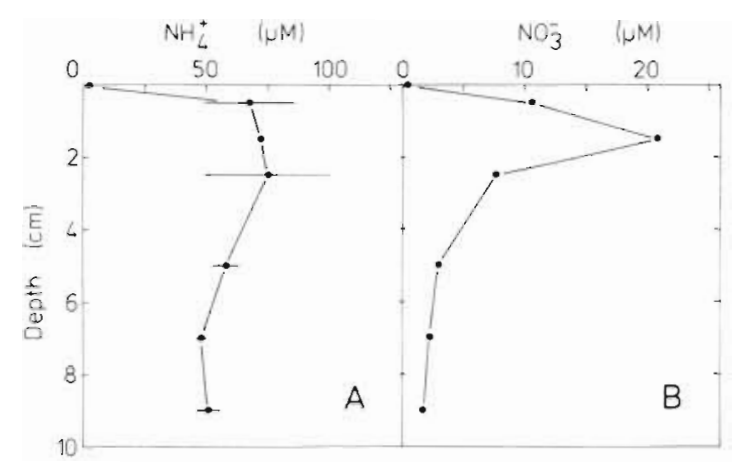

Fig. 1 Vertical profiles of (A) porewater $\mathrm{NH}_{4}{ }^{+}$concentrations (means $\pm \mathrm{SE}$ of 3 cores) and $(\mathrm{B})$ porewater $\mathrm{NO}_{3}{ }^{-}$concentration. (Values based on 1 core)

above $4 \mathrm{~cm}$ depth than below $(p<0.05)$. However, this does not necessarily represent the average $\mathrm{NO}_{3}{ }^{-}$ pattern in this mangrove sediment. The presence of $\mathrm{NO}_{3}{ }^{-}$deep in the sediment may be caused by nitrification associated to oxidized burrow structures and rootsediment interfaces.

\section{Benthic oxygen uptake}

Oxygen generally penetrated ca $2 \mathrm{~mm}$ into sediments of the Ao Nam Bor mangrove (Fig. 2). The effect of light/dark cycles on $\mathrm{O}_{2}$ penetration were most dramatic when the sediment was covered with a stagnant water column. At the SUN station $\mathrm{O}_{2}$ penetrated $2.5 \mathrm{~mm}$ into the inundated sediment when exposed to sunlight, but only $1.5 \mathrm{~mm}$ in darkness. A similar but less dramatic pattern was observed at the SDW station, i.e. 2.0 to 2.5 and $2.0 \mathrm{~mm}$ penetration depth respectively. At both stations the $\mathrm{O}_{2}$ concentration at the sediment-water interface was undersaturated in darkness: $67 \%$ (SUN) and $57 \%$ (SDW) of full air saturation. In daylight, however, the interface became supersaturated with $\mathrm{O}_{2}$ (SUN: $136 \%$; SDW: $103 \%$ ) due to microalgal photosynthesis. In air-exposed sediment $\mathrm{O}_{2}$ penetration depth was similar in both light and dark- ness. Thus, at the SUN station $\mathrm{O}_{2}$ penetrated constantly $1.5 \mathrm{~mm}$ into the sediment, whereas the SDW station exhibited a stable $2 \mathrm{~mm}$ oxic zone. The effect of light on $\mathrm{O}_{2}$ concentration in air exposed sediment was detectable as supersaturation close to the surface; $146 \%$ (SUN) and $128 \%$ (SDW).

The estimated diffusive $\mathrm{O}_{2}$ uptake was influenced by both water cover and sediment-type. Highest rates were obtained for sediments exposed to air in both light and darkness (SUN: $0.77 \pm 0.09 \mathrm{mmol} \mathrm{m}^{-2} \mathrm{~h}^{-1}$ and SDW: $0.59 \pm 0.05 \mathrm{mmol} \mathrm{m}{ }^{-2} \mathrm{~h}^{-1}$, Table 2), whereas the lowest rates were found for water covered sediments in darkness (SUN: $0.36 \pm 0.07 \mathrm{mmol} \mathrm{m} \mathrm{m}^{-2} \mathrm{~h}^{-1}$ and SDW: $0.33 \pm 0.02 \mathrm{mmol} \mathrm{m}^{-2} \mathrm{~h}^{-1}$ ). The latter values, which are significantly lower than those obtained from exposed sediments $(p<0.05)$, apparently underestimate the true diffusive $\mathrm{O}_{2}$ flux by ca $50 \%$ due to undersaturation at the sediment surface. Average diffusive $\mathrm{O}_{2}$ uptake was 1.29 times higher in exposed SUN than in exposed SDW sediment ( $p \sim 0.05$ ) (Table 2 ). Rates of $\mathrm{O}_{2}$ uptake measured directly by dark core incubations were 1.56 (SUN, $p<0.01$ ) and 1.19 (SDW, $p \sim 0.10$ ) times higher than the estimated diffusive flux (Table 2). Thus, the directly measured flux in SUN sediment was 1.68 times higher than in SDW sediment $(p<0.01)$.

\section{Benthic primary production}

Primary production by the benthic microalgae appeared negatively affected by shading of Rhizophora

Table 2. Comparison of sediment $\mathrm{O}_{2}$ uptake determined either from core incubations in darkness or estimated from $\mathrm{O}_{2}$ profiles. Results from SUN and SDW station. Profile data are from measurements on cores without water cover. Means \pm SE of 3 and 8 measurements respectively. Values are in $\mathrm{mmol} \mathrm{m} \mathrm{m}^{-2} \mathrm{~h}^{-1}$

\begin{tabular}{|lcc|}
\hline Method & \multicolumn{2}{c|}{$\mathrm{O}_{2}$ uptake } \\
\hline & $\mathrm{SUN}$ & $\mathrm{SDW}$ \\
Incubation & $1.19 \pm 0.05$ & $0.71 \pm 0.13$ \\
Profile & $0.77 \pm 0.09$ & $0.59 \pm 0.05$ \\
\hline
\end{tabular}



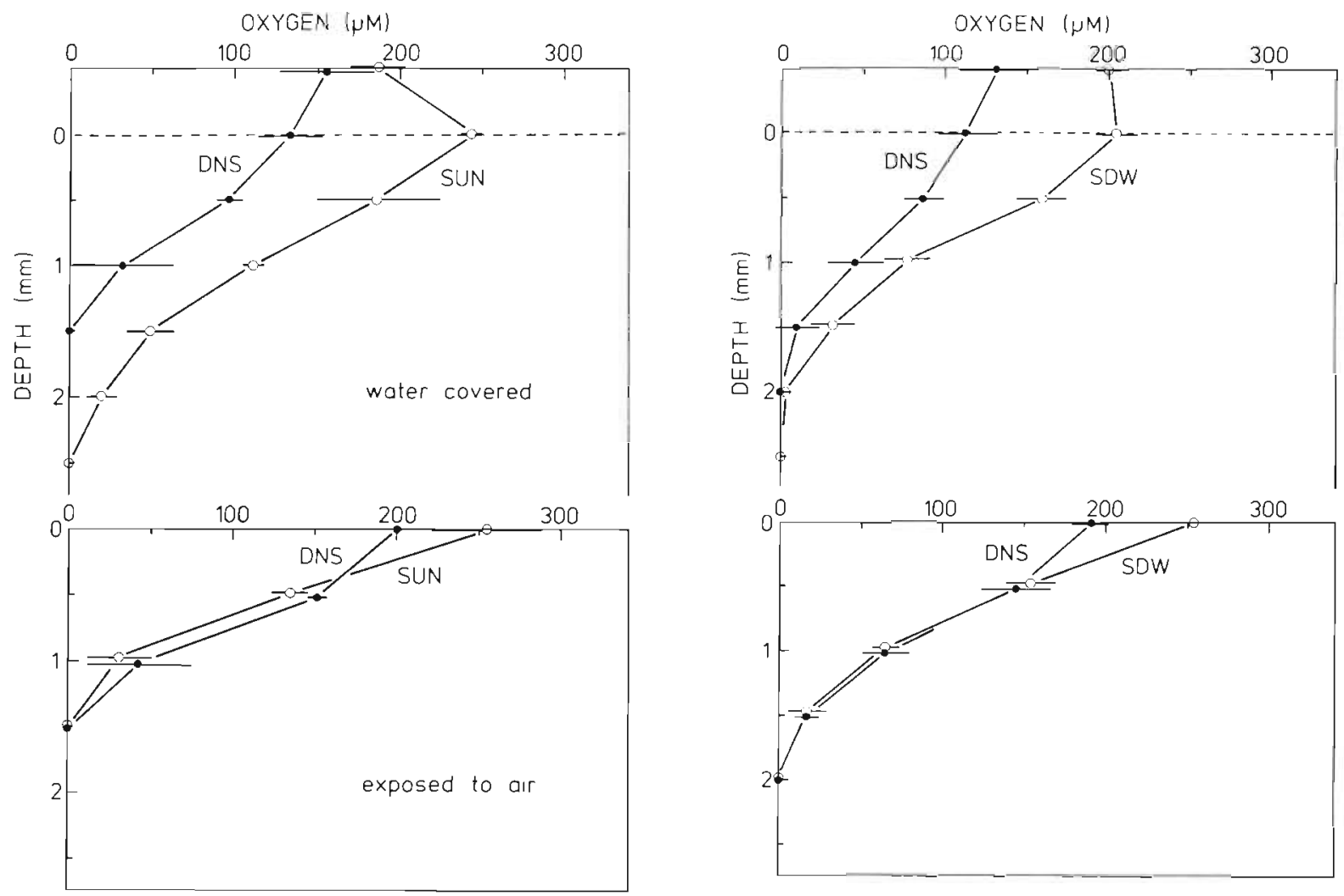

Fig. 2. Vertical profiles of $\mathrm{O}_{2}$ in the surface layer of mangrove sediments. Left: sun-exposed sediment in light (SUN) and darkness (DNS). Right: sediment shaded by Rhizophora apiculata in light (SDW) and darkness (DNS). Profiles shown for water covered (upper) and air exposed (lower) sediments. Means \pm SE of 4 measurements

apiculata (Table 3). The assimilation of ${ }^{14} \mathrm{C}$ and gross $\mathrm{O}_{2}$ production (production in light + uptake in darkness) were $1.4(p<0.05)$ and $1.7(p<0.025)$ times higher at the SUN station than at the SDW station. However, the community photosynthetic quotient (CPQ) at the 2 stations (SUN: 1.47 ; SDW: $1.26 \mathrm{~mol} \mathrm{O}_{2}$ / $\mathrm{mol}$ C) was not significantly different from $1(p>0.05)$.

Net $\mathrm{O}_{2}$ production in light was, SUN: 0.87 and SDW: $0.51 \mathrm{mmol} \mathrm{m}^{-2} \mathrm{~h}^{-1}$. On a daily basis (12 h light, $12 \mathrm{~h}$ darkness), however, $\mathrm{O}_{2}$ uptake by the heterotrophic community exceeded the production by the benthic microalgae, i.e. a net $\mathrm{O}_{2}$ uptake of 7.6 and $4.7 \mathrm{mmol}$ $\mathrm{m}^{-2} \mathrm{~d}^{-1}$ respectively.

The biomass of benthic microalgae at the 2 stations,

Table 3. Chlorophyll a content ( $\mathrm{mg} \mathrm{m}^{-2} ; 0$ to $3 \mathrm{~mm}$ ), gross $\mathrm{O}_{2}$ production ( $\mathrm{mmol} \mathrm{m}-2 \mathrm{~h}^{-1}$ ) and ${ }^{14} \mathrm{C}-\mathrm{CO}_{2}$ assimilation in mangrove sediments, exposed to direct sunlight (SUN) or shaded by trees (SDW). Mean \pm SE of 3,4 and 4 measurements respectively

\begin{tabular}{|lccc|}
\hline Station & $\begin{array}{c}\text { Chlorophyll } \\
\text { a }\end{array}$ & $\begin{array}{c}\text { Gross } \mathrm{O}_{2} \\
\text { production }\end{array}$ & $\begin{array}{c}\mathrm{CO}_{2} \\
\text { assimilation }\end{array}$ \\
\hline SUN & $19.2 \pm 2.2$ & $2.06 \pm 0.18$ & $1.40 \pm 0.15$ \\
SDW & $15.5 \pm 2.3$ & $1.22 \pm 0.21$ & $0.97 \pm 0.10$ \\
\hline
\end{tabular}

measured as chlorophyll $a$ in the upper 0 to $3 \mathrm{~mm}$ sediment layer, is shown in Table 3. The chlorophyll a content at the 2 stations was not significantly different $(p>0.05)$, although the value for the SUN station appeared $24 \%$ higher than that for the SDW station. The assimilation number (mg C $\left[\mathrm{mg} \mathrm{Chl} \mathrm{a}^{-1} \mathrm{~h}^{-1}\right.$ ) was 0.75 (SDW) -0.88 (SUN) from ${ }^{14} \mathrm{C}$ assimilation data and 0.95 (SDW) - 1.28 (SUN) from gross $\mathrm{O}_{2}$ production data based on a CPQ of 1.0 (Andersen \& Kristensen 1988).

\section{Dissolved inorganic nitrogen flux}

Vertical gradients of pore water $\mathrm{NH}_{4}{ }^{+}$and $\mathrm{NO}_{3}{ }^{-}$ close to the sediment surface indicated an upward flux of DIN (Fig. 1). The directly measured DIN flux, however, was always directed towards the sediment-water interface (Table 4). No consistent relationship between DIN uptake by the sediment and light/dark cycles was found. The scatter in the data, especially for $\mathrm{NH}_{4}{ }^{+}$, may have blurred any particular relation.

\section{Import-export}

The tidal samplings indicated a substantial import of suspended particulate carbon (PC) and nitrogen (PN) 
Table 4. Fluxes of DIN $\left(\mathrm{NH}_{4}^{+}, \mathrm{NO}_{3}^{-}\right)$from overlying water into sediment. Means $\pm \mathrm{SE}$ of 3 measurements for SUN and SDW stations in light and darkness. Values are in $\mu \mathrm{mol} \mathrm{m} \mathrm{m}^{-2} \mathrm{~h}^{-1}$

\begin{tabular}{|cccc|}
\hline Station & $\mathrm{NH}_{4}^{+}$flux & $\mathrm{NO}_{3}^{-}$flux & $\begin{array}{c}\text { Total } \\
\text { DiN flux }\end{array}$ \\
\hline SUN & & & \\
light & $38.7 \pm 63.9$ & $43.9 \pm 23.4$ & 82.6 \\
dark & $29.2 \pm 22.9$ & $30.6 \pm 2.7$ & 59.8 \\
SDW & & & \\
light & $72.7 \pm 33.4$ & $29.7 \pm 12.0$ & 102.4 \\
dark & $103.5 \pm 78.5$ & $50.7 \pm 4.3$ & 154.2 \\
\hline
\end{tabular}

during rising tides (Fig. 3). When water entered the channel at high velocity, the concentration of suspended material almost doubled within $1 \mathrm{~h}$ (Fig. $3 \mathrm{C}$ ); subsequently a decrease occurred in proportion to water velocity. Water leaving the channel during receding tide was low in suspended particles. The C:N ratio of the particulate matter was lowest at low tide (115), but increased when water entered the channel at rising tide (Fig. 3D). Maximum C:N was reached at the highest water level (175).

Ammonium in the channel water was almost depleted at high tide (Fig. 3 B). However, the decrease from 2.8 to $0.1 \mu \mathrm{M}$ commenced more than $2 \mathrm{~h}$ before any water water entered the channel. This indicates that factors other than tides may be responsible for $\mathrm{NH}_{4}^{+}$removal. The concentration of $\mathrm{NO}_{3}^{-}$was low throughout the tidal cycle, 0.3 to $0.5 \mu \mathrm{M}$. The highest concentration was observed at the end of the high tide period.

\section{DISCUSSION}

The biomass of benthic microalgae in the tropical Ao Nam Bor mangrove agrees with data from 5 Australian mangroves (Alongi 1988). However, estimates of both biomass and primary production (Table 3 ) are low compared to values from intertidal flats of the temperate zone (e.g. Colijn \& Jonge 1984). The assimilation number of the mangrove algae 10.75 to $1.28 \mathrm{mg} \mathrm{C}$ [ mg $\mathrm{Chl} a]^{-1} \mathrm{~h}^{-1}$ ), on the other hand, j.s in the upper range of that previously found in situ for benthic microalgae (Cadee \& Hegeman 1974, Admiraal \& Peletier 1980, Rasmussen et al. 1983, Calijn \& Jonge 1984). Such high assimilation numbers, indicating high photosynthetic efficiencies, are characteristic of microalgae from tropical waters (Parsons et al. 1984b).

Shading by macrophytes is a well-known limiting factor for benthic primary production in intertidal areas (Van Raalte et al. 1976). The reduction of both microalgal biomass $(20 \%$ ) and primary production (31 to $41 \%$ ) beneath the canopy of Rhizophora apiculata
(SDW) relative to the sun exposed sediment (SUN) indicate that light limitation may occur at the former station. Thus, the shadow effect of $R$. apiculata explains the observed difference in microalgal biomass and production between the 2 stations, but the overall low benthic primary production in the Ao Nam Bor mangrove is caused by other factors.

Nutrient availability (i.e. inorganic nitrogen) may limit benthic microalgal production in intertidal areas (van Raalte et al. 1976, Darley et al. 1981, Rutgers van der Loeff et al. 1981). The pools of dissolved inorganic nitrogen (DIN $=\mathrm{NO}_{3}^{-}+\mathrm{NH}_{4}^{+}$) in the Ao Nam Bor mangrove (overlying water, 0.4 to $3.0 \mu \mathrm{M}$; sediment pore water, 50 to $90 \mu M_{i}$ Figs. 1 and $3 B$ ) are several times smaller than those usually found in intertidal areas (Hartwig 1978, Rutgers van der Loeff et al. 1981). Accordingly, the dichotomy between the expected DIN flux across the sediment-water interface, deduced from the vertical profiles of $\mathrm{NH}_{4}^{+}$and $\mathrm{NO}_{3}^{-}$(Fig. 1), and the directly measured DIN flux (Table 4) suggests that microalgae at the sediment surface may be DIN starved. The algae assimilates DIN both from below and above the sediment-water interface, despite low concentration in the overlying water, thereby acting as a 'filter' for the DIN flux from the sediment (Henriksen et al. 1980, Andersen \& Kristensen 1988). The sediment DIN uptake observed in darkness may partially be caused by continued algal (and root) assimilation during nonphotosynthetic periods as observed by Andersen \& Kristensen (1988). Microalgae that become nitrogen deficient during the day are known to make up for the deficiency by assimilation of DIN in the dark (Dugdale \& Goering 1967, Kristensen unpubl.). This may particularly be true in the present study because the dark incubations were initiated less than $1 / 2 \mathrm{~h}$ after the light incubations.

The DIN dynamics within a mangrove swamp should be reflected in the water of the adjacent tidal channels (Fig, $3 \mathrm{~B}$ ). The gradually decreasing $\mathrm{NH}_{4}^{+}$concentration observed in the morning before the tide enters the channel may representsediment uptake due to increasing photosynthesis of the mangrove flora. When the tide reaches the channel, the concentration of $\mathrm{NH}_{4}^{+}$ in the channel water and incoming seawater are similar. At low tide in the afternoon the concentration of $\mathrm{NH}_{4}^{+}$returns to a higher level due to ceased plant uptake and percolation from the channel banks. The tidal concentration pattern of $\mathrm{NO}_{3}^{-}$suggests that higher nitrification occurs at high tide than low tide. However, the exact influence of nitrification and plant uptake on the DIN dynamics in channel waters needs to be assessed by following the concentration pattern during several tidal cycles; both during day and night.

Oxygen penetration depth found for the present mangrove sediment (Fig. 2) is within the range usually 
found in silty intertidal sediments (Revsbech et al. 1980, Revsbech \& Jørgensen 1986). The estimates of $\mathrm{O}_{2}$ uptake by the mangrove sediment, derived from the profiles in air exposed sediment cores, only account for 64 to $84 \%$ of the measured total $\mathrm{O}_{2}$ uptake (Table 2). Similarly, Revsbech \& Jørgensen (1986) and Andersen \& Helder (1987) noted that $\mathrm{O}_{2}$ uptake rates estimated from profiles generally are in the range of 30 to $90 \%$ of measured total rates. Estimated rates represent a balance between diffusional supply of $\mathrm{O}_{2}$ to the sediment and rate of $\mathrm{O}_{2}$ consumption in the sediment. Oxygen profiles therefore only reflect microbial and chemical $\mathrm{O}_{2}$ demand, whereas the directly measured total rates, in addition, include the demand from the macro- and meiofauna present. Some of the difference may also be caused by the irregular topography of the sediment surface.

The present study provides, although with spatial and temporal limitations, the basis for a preliminary quantitative evaluation of benthic community metabolism in the Ao Nam Bor mangrove. Gross and net daily benthic primary production are 12 to 25 and 6 to $10 \mathrm{mmol} \mathrm{C} \mathrm{m} \mathrm{C}^{-2} \mathrm{~d}^{-1}$ respectively, when extrapolated to $12 \mathrm{~h}$ daylight. Estimates of tree production in the Ao Nam Bor mangrove forest, based on litterfall data corrected for production of twigs, trunks and roots (Bunt et al. 1979), are 118 to $172 \mathrm{mmol} \mathrm{C} \mathrm{m}^{-2} \mathrm{~d}^{-1}$ (S. Poovachiranon pers. comm.). Accordingly, benthic primary production may account for 4 to $20 \%$ of the tree production in this mangrove (exclusive of epiphytic micro- and macroalgae on mangrove roots).

Rate of $\mathrm{O}_{2}$ uptake, which usually measures the oxidation of organic matter by both aerobic and anaerobic heterotrophs (Andersen \& Hargrave 1984, Kristensen \& Blackburn 1987, Andersen \& Kristensen 1988) indicates a relatively low rate of decay in this mangrove sediment. However, this approach should be taken with caution, because the motile benthic fauna (e.g. sesarmid crabs) will not be included in assays of benthic $\mathrm{O}_{2}$ uptake. These animals may consume a large fraction of the litterfall (Robertson 1986, Kofoed unpubl.). Organic matter originating from Rhizophora apiculata, except for the leachable fraction, is known as refractory to microbial decay in the sediment (Rice \& Tenore 1981, Benner \& Hodson 1985). Dead algal cells on the other hand, generally decompose 5 to 10 times faster than leaf tissues (Boonruang 1978, Rice \& Tenore 1981, Twilley et al. 1986a). Benthic algae may therefore represent an essential input of labile organic matter to the microbial detritus food chain, as stressed by the close correlation between benthic primary production and $\mathrm{O}_{2}$ uptake at the 2 stations (Tables 2 and 3). The diurnal $\mathrm{O}_{2}$ uptake, corrected for algal decay $\left(\mathrm{O}_{2}\right.$ demand during organic carbon decay equals $\mathrm{O}_{2}$ evolution during organic carbon production), provides 4.7 to
$7.6 \mathrm{mmol} \mathrm{O}_{2} \mathrm{~m}^{-2} \mathrm{~d}^{-1}$ (i.e. $27 \%$ of total dark $\mathrm{O}_{2}$ uptake) for the decomposition of tree material (including epiphytic algae) in the sediment. This is much less than needed for a total mineralization of all the tree material produced, even when leaching and assimilation by leaf

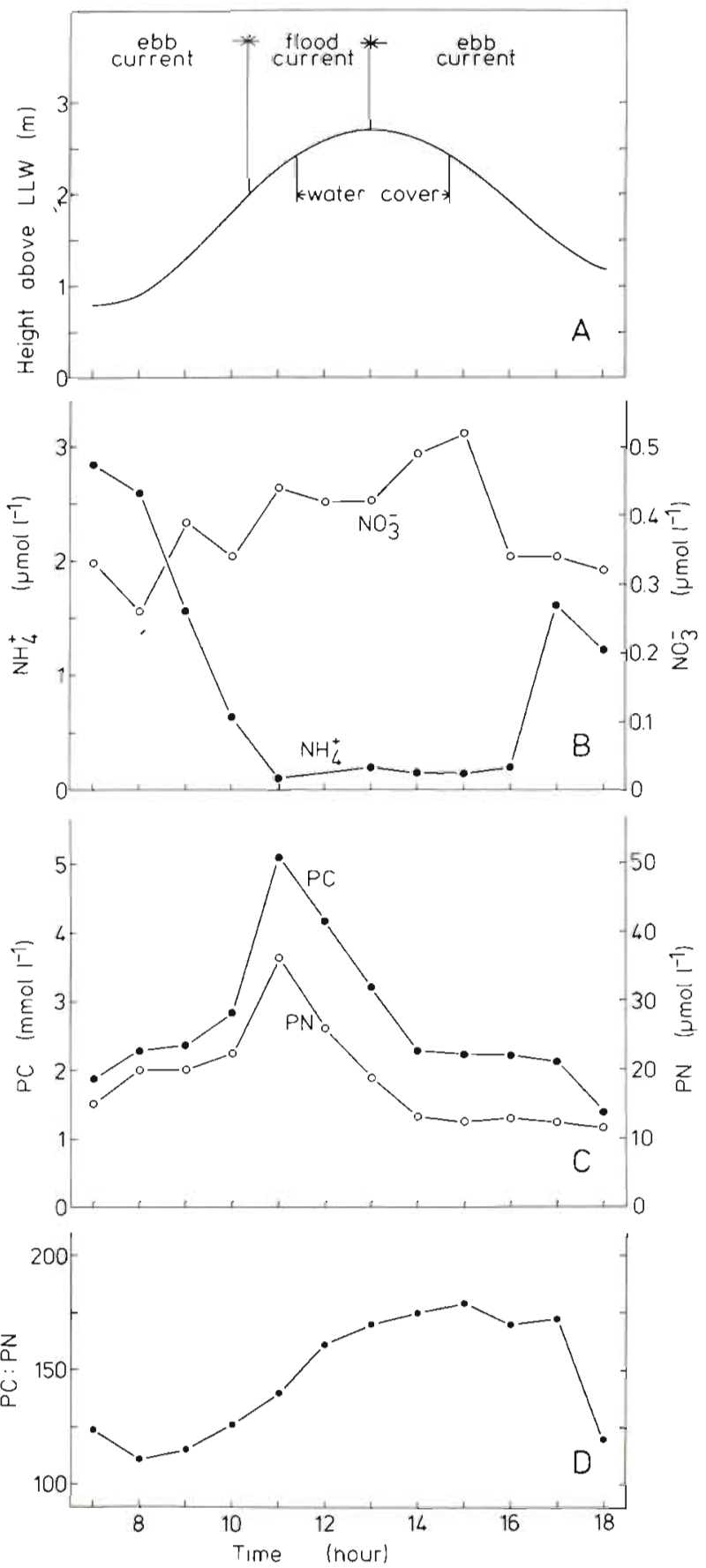

Fig. 3. Load of dissolved and suspended material in water samples from a tidal channel adjacent to the study site. One tidal period was followed. (A) Water level above LLW with indication of water current direction and inundation time at study site. (B) $\mathrm{NH}_{4}{ }^{+}$and $\mathrm{NO}_{3}{ }^{-}$concentration. (C) Particulate carbon and nitrogen. (D) $\mathrm{C}: \mathrm{N}$ ratio of suspended particles 
eating crabs are considered. The low mineralization rate of tree material indicates a net accumulation of low degradable organic matter in the Ao Nam Bor mangrove; in accordance with the commonly observed rapid accretion of mangrove forests in south-east Asia (Macnae 1968).

The 2-layered structure of the mangrove sediment is probably the combined result of sedimentation during high tides, faecal pellet deposition and root growth (Table 1). The high concentration of suspended particles in the water entering during high tides apparently originates from the tidal mudflat outside the mangrove forest (Fig. $3 \mathrm{C}$ ). When the flood reaches the mudflat, material that has been loosened by wave action is flushed into the mangrove swamp. Later at high tide, when the water current ceases, the material is deposited as a silt layer on the sediment surface. Sedimentation may be of considerable magnitude, since the difference in concentration of suspended particles in water entering and leaving the mangrove swamp is as

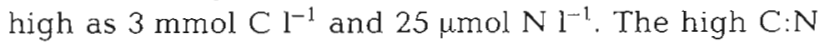
ratio of the suspended material suggests that a major fraction is carbonates probably of coral origin (Fig. 3 D). This is in contrast to the mangrove sediment that hardly contains any carbonates.

This study suggests that the benthic community in mangrove forests is an important site for organic matter production and decomposition. However, more work is needed to elucidate the following points: (1) temporal and spatial variations in benthic metabolism; (2) exact causes for the low benthic primary production; (3) quantitative significance of aerobic and anaerobic microbial decay of intact leaves, leaf detritus and microalgae; (4) role of tidal transport in organic matter dynamics in mangrove systems.

Acknowledgements. We are grateful to the staff of PMBC for much help during this study. We acknowledge B. Beckman, S. Hansen, U. Jensen, J. Lau, S. S. Madsen, A. F. Povlsen, B. T Rasmussen, F. Sode, M. Sørensen and J. K. Thomsen for help with the field work, and $H$. Brandt und $O$. Larsen for assistance during analytical work. This work was supported by travel grants No. 81-5653, 81-5654 and 81-5655 from the Danish Scjence Research Council.

\section{LITERATURE CITED}

Admiraal, W., Peletier, H. (1980). Influence of seasonal variations of temperature and light on the growth rate of cultures and natural populations of intertidal diatoms. Mar. Ecol. Prog. Ser. 2: 35-43

Alongi, D. M. (1988). Bacterial productivity and microbial biomass in tropical mangrove sediments. Microb. Ecol. 15: $59-79$

Andersen, F. Ø., Hargrave, B. T (1984). Effects of Spartina detritus enrichment on aerobic/anaerobic benthic metabolism in an intertidal sediment. Mar. Ecol. Prog. Ser. 16: $161-171$
Andersen, F. Ø., Helder, W (1987). Comparison of oxygen microgradients, oxygen flux rates and electron transport system activity in coastal marine sediments. Mar Ecol. Prog. Ser. 37: 259-264

Andersen, F. Ø., Kristensen, E. (1988). The influence of macrofauna on estuarine benthic community metabolism - a microcosm study. Mar. Biol. (in press)

Armstrong, F. A. J., Stearns, C. R., Strickland, J. D. H. (1967). The measurement of upwelling and subsequent biological processes by means of the Technicon Auto-analyser and associated equipment. Deep Sea Res. 14: 381-389

Benner, R., Hodson, R. E. (1985). Microbial degradation of the leachable and lignocellulosic components of leaves and wood from Rhizophora mangle in a tropical mangrove swamp. Mar. Ecol. Prog. Ser. 23: 221-230

Berner, R. A. (1980). Early diagenesis - a theoretical approach. Princeton University Press, Princeton, N. J.

Boonruang, $P$. (1978). The degradation rates of mangrove leaves of Rhizophora apiculata (Bl.) and Avicennia marina (Forsk.) Vierh. at Phuket Island, Thailand. Phuket Mar. Biol. Ctr Res. Bull. 26: 1-6

Broecker, W. S., Peng, T.-H. (1974). Gas exchange rate between sea and air. Tellus 26: 21-35

Bunt, J. S., Boto, K. G., Boto, G. (1979). A survey method for estimating potential levels of mangrove forest primary production. Mar. Biol. 52: 123-128

Cadée, G. C., Hegeman, J. (1974). Primary production of the benthic microflora living on tidal flats in the Dutch Wadden Sea. Neth. J. Sea Res. 8: 260-291

Christensen, B. (1978). Biomass and primary production of Rhizophora apiculata BI. in a mangrove in southern Thailand. Aquat. Bot. 4: 43-52

Colijn, F., Jonge, V. N. de (1984). Primary production of microphytobenthos in the Ems-Dollard Estuary. Mar Ecol. Prog. Ser. 14: 185-196

Cundell, A. M., Brown, M. S., Stanford, R., Mitchell, R. (1979). Microbial degradation of Rhizophora mangle leaves immersed in the sea. Estuar. coast mar. Sci. 9: 281-286

Darley, W. M., Montague, C. L., Plumley, F. G., Sage W. W., Psalidas, A. T (1981). Factors limiting edaphic algal biomass and productivity in a Georgia salt marsh. J Phycol. 17: $122-128$

Davey, A., Woelkerling, W. J. (1985). Studies on Australian mangrove algae. III. Victorian communities: structure and recolonization in Western Port Bay. J. exp. mar. Biol. Ecol. 85: $177-190$

Dugdale, R. C., Goering, J. J. (1967). Uptake of new and regenerated forms of nitrogen in primary productivity Limnol. Oceanogr. 12: 196-206

Dye, A. H., Lasiak, T. A. (1986). Microbenthos, meiobenthos and fiddler crabs: trophic interactions in a tropical mangrove sediment. Mar. Ecol. Prog. Ser. 32: 259-264

Frith, D. W. Tantanasiriwong, R., Bhatia, O. (1976). Zonation and abundance of macrofauna on a mangrove shore, Phuket Island. Phuket Mar. Biol. Ctr Res. Bull. 10: 1-37

Hartwig, E. O. (1978). Factors affecting respiration and photosynthesis by the benthic community of a subtidal siliceous sediment. Mar Biol. 46: 283-293

Henriksen, K., Hansen, J. I., Blackburn, T H. (1980). The influence of benthic infauna on exchange of inorganic nitrogen between sediment and water Ophelia, Suppl. 1. 249-256

Helder, W. Bakker, J. F. (1985). Shipboard comparison of micro- and minielectrodes for measuring oxygen distribution in marine sediments. Limnol. Oceanogr 30: 1106-1109

Jørgensen, B. B. (1983). Processes at the sediment-water inter- 
face. In: Bolin, B., Cook, R. B. (eds.) The major biogeochemical cycles and their interactions. John Wiley \& Sons, Chichester, p. 477-509

Kristensen, E., Andersen, F. Ø. (1987). Determination of organic carbon in marine sediments: a comparison of two CHN-analyzer methods. J. exp. mar. Biol. Ecol. 109: 15-23

Kristensen, E., Blackburn, T H. (1987). The fate of organic carbon and nitrogen in experimental marine sediment systems: influence of bioturbation and anoxia. J. mar. Res. 45: $231-257$

Leach, J. H. (1970). Epibenthic algal production in an intertidal mudflat. Limnol. Oceanogr. 15: 514-521

Li, Y.-H., Gregory, S. (1974). Diffusion of ions in sea water and deep-sea sediments. Geochim. Cosmochim. Acta 38: 703-714

Macnae, W. (1968). A general account of the fauna and flora of mangrove swamps and forests in the Indo-West-Pacific region. Adv. mar. Biol. 6: 73-270

Mook, D. H., Hoskin, C. M. (1982). Organic determination by ignition: caution advised. Estuar. coast. Shelf Sci. 15: $697-699$

Odum, W. E. Heald, E. J. (1975). The detritus-based food web of an estuarine mangrove community. In: Cronin, L. E. (ed.) Estuarine research. Academic Press, New York, p. 265-286

Parsons, T. R., Maita, Y., Lalli, C. M. (1984a). A manual of chemical and biological methods for seawater analysis. Pergamon Press, Oxford

Parsons, T. R., Takahashi, M., Hargrave, B. (1984b). Biological oceanographic processes. Pergamon Press, Oxford

Rasmussen, M. B., Henriksen, K., Jensen, A. (1983). Possible causes of temporal fluctuations in primary production of the microphytobenthos in the Danish Wadden Sea. Mar. Biol. 73: 109-114

Revsbech, N. P., Jorgensen, B. B. (1985). Microelectrodes: their use in microbial ecology. Adv. microb. Ecol. 9: 293-352
Revsbech, N. P., Sorensen, J., Blackburn, T H., Lomholt, J. P. (1980). Distribution of oxygen in marine sediments measured with microelectrodes. Limnol. Oceanogr. 25 403-411

Ricard, M. (1984). Primary production in mangrove lagoon waters. In: Por, F. D., Dor, I. (eds.) Hydrobiology of the Mangal. Dr W. Junk Publ., The Hague, p. 163-177

Rice, D. L., Tenore, K. R. (1981). Dynamics of carbon and nitrogen during the decomposition of detritus derived from estuarine macrophytes. Estuar. coast. Shelf Sci. 13 $681-690$

Robertson, A. I. (1986). Leaf-burying crabs: their influence on energy flow and export from mixed mangrove forests (Rhizophora spp.) in northeastern Australia. J. exp. mar. Biol. Ecol. 102: 237-248

Rutgers van der Loeff, M. M. Es, F. B. van, Helder, W. Vries R. T. de (1981). Sediment water exchanges of nutrients and oxygen on tidal flats in the Ems-Dollard Estuary. Neth. J Sea Res. 15: 113-129

Solórzano, L. (1969). Determinations of ammonia in natural waters by the phenolhypochlorite method. Limnol. Oceanogr. 14: 799-801

Twilley, R. R., Ejdung, G., Romare, P., Kemp, W. M. (1986a). A comparative study of decomposition, oxygen consumption and nutrient release for selected aquatic plants occurring in an estuarine environment. Oikos 47: 190-198

Twilley, R. R., Lugo, A. E., Patterson-Zucca, C. (1986b). Litter production and turnover in basin mangrove forests in southwest Florida. Ecology 67: 670-683

Van Raalte, C. D., Valiela, I., Teal, J. M. (1976). Production of epibenthic salt marsh algae: light and nutrient limitation. Limnol. Oceanogr. 21. 862-872

Wium-Andersen, S. (1979). Plankton primary production in a tropical mangrove bay at the south-west coast of Thailand. Ophelia 18: 53-60 